\title{
Sinedigma: Sinemanın Zihinsel ve Toplumsal Gerçeklik Üretimi
}

\author{
Gökhan Gültekin*
}

Özet

Bu çalışmanın amacl, özgün ve sinemaya özgü bir kavram olarak ileri sürülen 'sinedigma'nın, zihinsel gerçeklik algısında ne kadar etkili olduğuna ve bu etkinin nasıl toplumsal hâle gelebildiğine dair düşünce üretme çabasıdır. Bu amacı ortaya koymak adına, çalışma literatür taramasını merkeze alarak kuramsal bir eksene yerleştirilmiştir. Bu eksen dâhilinde, öncelikle gerçeklik ve sinema arasındaki ilişkiye değinilmiş, gerçeklikle ilişkisi açısından sinedigma kavramının tam olarak neyi ifade ettiği ve zihinsel gerçeklikler üzerindeki etkisinin nasıl olduğu açıklanmaya çalışılmıştır. Daha sonra sinedigmaların toplumsal gerçeklik üzerindeki etkisi tartışılarak, kültürel oluşumda ne tür bir rolü olabileceğine dair düşünceler ortaya koyulmuştur. Sonuç olarak, sinedigmaların her geçen gün daha da evrenselleşerek hem bireysel hem de toplumsal gerçeklikler üretebildiği savunulmuştur.

Anahtar Kelimeler: Sinedigma, Gerçeklik, Sinema

ORCID ID : https:/ / orcid.org/ 0000-0002-7928-3829

E-mail : cinegultekin@gmail.com

DOI:10.31122/sinefilozofi. 788370

Geliș Tarihi - Recieved: 31.08.2020

Kabul Tarihi - Accepted: 13.12.2020 


\title{
Sinedigma: The Mental and Social Reality Construction of Cinema
}

\author{
Gökhan Gültekin*
}

\begin{abstract}
The aim of this study is to try to generate an idea about how effective 'sinedigma' -which is put forward as an original concept specific to cinema- is in the perception of mental reality, and how this effect can become social. In order to reveal this aim, the study was placed on a theoretical axis centring on a literature review. Within this axis, first, the relationship between reality and cinema was mentioned; an attempt was made to explain exactly what the concept of sinedigma expresses in terms of its relationship with reality, and what effect it has on mental realities. Later, opinions about what kind of role sinedigmas can play in cultural formation were put forth by debating their impact on social reality. In conclusion, it has been asserted sinedigmas are becoming increasingly universal and they are capable of generating both individual and social realities.
\end{abstract}

Key words: Sinedigma, Reality, Cinema

ORCID ID : https:/ / orcid.org/ 0000-0002-7928-3829

E-mail : cinegultekin@gmail.com

DOI:10.31122/sinefilozofi.788370

Geliş Tarihi - Recieved: 31.08.2020

Kabul Tarihi - Accepted: 13.12.2020 


\section{Giriş}

Sinema, insanların anlamlandırma pratiklerine yardımcı olduğu gibi, tutum ve davranışlarının şekillendirilmesine de etki edebilmektedir. Sinema ürünleri olan filmlerin, zaten var olan kültürü sunduğu yönünde görüşler olmakla birlikte, gerçek olmayan; fakat sonradan benimsenen fantezileri aktardığına dair yorumlar da bulunmaktadır. Bu iki kutuplu anlayış, belirli açılardan haklılık payına sahiptir. Sinema, gerçeklikten topladığı malzemelerle filmler üretmektedir. Buna şüphe yoktur; fakat bu filmler aynı zamanda hiç var olmayan bir gerçekliğin benimsenmesini de sağlayabilir (Monaco, 2010: 250). Zaten filme dair en önemli nokta, Frampton'un (2013: 240) da vurguladığı gibi, "filmin insanlara yeni bir gerçeklik göstermesi, dolayısıyla yeni bir düşünme biçimi, yeni deneyimler, yeni duygular kazandırmasıdır." Böyle bir görüş, bizi sinemanın ürettiği gerçeklik fikrine götürür; özünden yeniden doğan bir gerçeklik. Bu gerçeklik, sinemanın ne gerçeği olduğu gibi sunması ne de kurgu, kamera, 1şık, ses, müzik ve renk gibi dinamikleri aracılığıyla gerçeklik üzerine yaptığı müdahaleyle açılanabilir. Burada 'etki' ve 'değişim' olmak üzere iki katmanlı bir durum söz konusudur. Etki katmanı, sinemanın bünyesindeki içerik ve biçimsel her türlü değeri işaret eden sinema paradigmasının, zihinsel ve toplumsal gerçeklik(ler) üzerindeki etkisini vurgular. İkinci katmandaki değişim ise sinema paradigmasının toplumsal ve teknolojik gelişmelere bağlı olarak geçirdiği dönüşümler ve bu dönüşümlerin zihinsel ve toplumsal gerçekliklere nasıl yansıdı ğıyla alakalıdır. Dolayısıyla sinema paradigmasının etki ve değişim özellikleri üzerinden özgün olarak yeniden kavramsallaştırılması gerekliliği ortaya çıkar; çünkü filmler bir bütün şeklinde zihinsel ve toplumsal gerçeklikleri etkilemediği gibi, sadece sinema paradigmasındaki sabit kodlarla da hareket etmez. Öte yandan, filmlerin kendi kod yapılarındaki değişimler aracılığıyla zihinsel ve toplumsal gerçeklikleri de değiştirme gücünü elinde bulundurduğu söylenebilir. İşte tüm bu gerçeklik üretimi ve değişimini sağlayan sinema paradigmasındaki herhangi bir içerik ya da biçimsel değer (kod), sadece sinemaya özgü bir kavram olarak 'sinedigma' şeklinde adlandırılabilir.

Sinedigmalar, bir kişinin gerçekliğine (zihinsel) etki edebileceği gibi, tüm seyirci kitlesinin veya onların temas ettiği herkesin (toplumsal) değerlerinde de değişime sebep olabilir. Bu durumda, bir çeşit sinema kültürünün oluşabileceğini söylemek gerekir; ancak bu kültür, filmleri izleme pratikleri bağlamında bir 'seyir kültürü' değil, film(ler)den edinilen gerçekliklerle oluşan bir çeşit 'seyrin kültürü'dür. Bu minvalde, Orhan Pamuk'un Kara Kitap'ta sinema aracılığıyla yayılan değerler üzerine aktardıkları, sinedigmaların toplumsal gerçekliklere olan etkisiyle nasıl bir kültür oluşturabileceğine iyi bir örnek olabilir. Pamuk'a (2011: 68) göre sinema, Anadolu insanının yeni tutum ve davranışlar benimsemesine; kahkaha şekilleri, pencere ya da kapı açma/kapama tarzları, ceket giymeler, yumruk atmalar, baş sallamalar, kibar öksürükler, göz hareketleri vs. sebep olmuştur. Tüm bunlar, sinema paradigmasından seçilen kod ya da alt kodlar sayesinde insanlarda kabul gören gerçekliklerdir. Bu tür gerçekliklerin genişlemesiyle, sinemanın da yoğun şekilde etkilediği bir çeşit seyrin kültüründen bahsetmek mümkün olabilir.

Filmde kullanılmak üzere seçilen bir görüntü, ses, tutum ya da davranış, insanların gerçeklik algısında, tutum ya da davranışlarında etkili olabilmektedir. Dolayısıyla bu tür bir etkiden söz ederken sinemadan ziyade, sinemasal değerleri ifade eden sinedigmalara vurgu yapmak daha doğru olacaktır. Bu yüzden, örneğin filmsel gerçekliklere maruz kalan seyircinin, bu gerçeklikleri aynı zamanda günlük yaşam pratiklerine uyguladığını söyleyen Pezzella'nın (2006: 17) görüşleri eksik görünür. Bu çalışmanın amac1, bu ve benzeri görüşlerden farklı şekilde, tüm bir sinema evreninin ya da baştan sona herhangi bir filmin değil, sinemaya özgü bir kavram olarak ortaya koyulan sinedigmaların gerçeklik üzerine etkisine dair düşünce üretme çabasıdır. Bu amaç dâhilinde özgün bir kavram olarak açıklanmaya çalışılan sinedigmanın, hem zihinsel hem de toplumsal gerçekliklere etkisinin nasıl olabileceği, örneklerle tartışılmıştır. 


\section{Seyircide Gerçeklik Üreticisi Olarak Sinedigma}

İnsanoğlu içine düştüğü evrenin gerçekliğini çözmeyi arzular. Dolayısıyla gerçeğin ne olduğu, insanlığın varoluş problematiğinin temelini oluşturur. Felsefi düşünceler, mitolojiler, dinler, sanat dalları, bilimsel keşifler ya da icatlara bakıldığında, bir şekilde gerçeğin ne olduğunun, nasıl yaşandığının veya ne olması gerektiğinin temele alındığı anlaşılır. Tüm bu alanlar, gerçeğe dair birçok alg1 oluşturur. Bu yönden Adanır (2012: 24), algilardan söz edildiğinde gerçeklikten söz etmemenin olanaksızlığına vurgu yapar. Yine de bir şeyin sadece algılanıyor oluşunun, gerçekliği için yeterli olmadığını belirtmek gerekir; çünkü bir şeyin gerçekliği, o şeyin gerçekliğine inananların varlığıyla mümkündür (Bernard, 2006: 106). Başka bir deyişle, gerçekliği düzenleyen şey, inançtır (Zizek, 2011: 51). Kimin, neye inandığ1 ise gerçekliğin kişiden kişiye değişebileceğini destekler. Bu açıdan Laing'in (2012: 35-36) şizoid bireyler üzerinden aktardıkları, iyi bir örnek olabilir. Ona göre gerçeklik, çoğu kişi için sözcüklerin doğal dünyayla bağlantısındadır. Örneğin normal bir kişinin "yaşıyorum" demesi, bunu söyleyen kadar hepimizin gerçekliği kabul edilebilir; fakat bir şizoid "ölüyüm" diyebilir ve bu bizim için gerçek olmasa da onun gerçeğidir. Dolayısıyla ölüm ve yaşamın gerçekliği mutlak gibi görünse bile, iki farklı kişi için aynı anlamda geçerli olmayabilir.

Gerçek, gerçeklik ya da hakikat gibi kavramlar anlamsal açıdan farklılaşabilmektedir. Bu yönden Wood (2010: 140), gerçekliğin gerçeğe denk düşmediğine vurgu yapar. Sözlük anlamında da bu farlılığı görmek mümkündür. Gerçek, “ideal, koşullu, potansiyel ya da olanaklıya karşıt biçimde; aktüel, somut, olgusal ve zihinden bağımsız bir varoluşa sahip olan" şeklinde ifade edilir. Gerçeklik ise "dış dünyada nesnel bir varoluşa sahip olan varlık, var olanların tümü; bilinçten, bilen insan zihninden bağımsız her şey" olarak kavramsallaşmaktadır (Cevizci, 1999: 377-378). Bununla birlikte, burada gerçek ve gerçeklik ayrımına gidilmemiş, gerçeklik Cündioğlu'nun (2012: 103) da vurguladığı şekliyle, “zihin ile dış dünya arasındaki mutabakat" olarak kullanılmıştır. Yine hakikat kavramı da aynı şeyi ifade etmektedir. Dolayısıyla bir şeye ait imge, söylem ya da sesin zihnen kabul edilmesinin, bu çalışmada 'gerçek', 'gerçeklik' ya da 'hakikat' kavramlarıyla ifade edilebilmesi için yeterli olduğu düşünülmüştür.

Gerçek mutlak değil, değişken yapıda bir olgudur (Bernard, 2006: 70). Kişiden kişiye değişebildiği gibi, toplumdan topluma ya da çağdan çağa da değişebilmektedir. Böyle bir düşünceden hareketle Lèvy-Bruhl, ilkel insan için bir şeyin gerçekliğine tanık olunmasa bile, gerçek olduğunu hissetmenin yeterli olduğuna değinir (Akt. Adanır, 2012: 24). Platon'un (2011: 231-232) 'mağara alegorisi', bu yönden ilkel insanın gerçeğe bakışını açılar niteliktedir. Bu alegoride, mağarada zincire vurulmuş ve sadece gözlerinin önündeki duvarı görebilenler, arkalarında ise dışarıda yanan bir ateş ve bu ateşin önünde ellerinde türlü nesneler olan başka kişiler bulunur. Mağaradakilerin tek gerçeği, ateşin önündeki bu insanların hareketleri ve onların ellerinde bulunan nesnelerden önlerindeki duvara düşen gölgelerdir. Yine gelen sesler de gölgelerin sesidir; kime ya da neye ait olduğu bilinmez. Dolayısıyla mağaradaki ilkel insanların gözünde gerçek, Platon'un tam anlamıyla ifade ettiği gibi, "yapma nesnelerin gölgelerinden başka bir şey değildir." İlkel-modern karşıtlığı açısından düşünüldüğünde, modern insanın da benzer bir durumun içinde olduğu söylenebilir. Modern insan da kendine sunulduğu kadarıla gerçeği yaşar. Bu açıdan düşünüldüğünde, görünüşler hükümdarlığında sıkışan modern insanın savunabileceği bir gerçeklik kalmadı ğını söyleyen Rancière (2013: 27), haklı olabilir. Dahası, 'imge-yoğun', 'söylem-yoğun' ve 'ses-yoğun' olarak şekillenen günümüz dünyası, Platon'un mağarasıyla kıyaslanabilir. Özellikle kitle iletişim araçlarının ve sanat dallarının imge, söylem ve sesleri aracılığıyla oluşturulan gerçeklikleri kabullenen modern insan, mağaradaki ilkel insandan çok da farklı değildir. Aradaki en temel fark, Deleuze'ün (1997: 256) görüşlerinden hareketle açıklanabilir. Ona göre Platon, mağara alegorisini ortaya koyarken 'kopya' ve 'simülakr' arasında ayrım yapmıştır. Kopya, saf ideaların doğru bir temsiliyken; simülakr, bu idealardan sapmaya işaret eden sahte gerçekliklerdir. Günümüz 
dünyasında ise kopya tamamen ortadan kalkmış ve simülakrlar kendi hükümdarlığını ilan etmiştir. Buna bağl1 şekilde, gerçek artık minyatürleşmiş hücreler, matrisler, bellekler ya da komutlarla oluşturulabilmektedir. Böylece gerçeğin sonsuz yeniden üretimi mümkün hâle gelmiştir. Dolayısıyla rasyonel gerçek, yerini işlemsel gerçeğe bırakmıştır. Artık sentetik şekilde üretilen bir hiper-gerçeklik bulunmaktadır ve hiper-gerçeklik, modern insanı bir simülasyon çağına sokmuş durumdadır (Baudrillard, 2011: 15). Bu sebepten, günümüzde gerçek ve simulakr arasında ayrım yapmak zorlaşmaktadır. Artık gerçek, yeniden üretilenden (simulakr) ayırt edilemiyorsa, herhangi bir imgenin gerçek olarak sunulması olağandır (Pezzella, 2006: 29).

İmgeler, yeniden üretilmiş görünümlerdir (Berger, 2012: 9). Bu yeniden üretimde, bağl1 oldukları gerçeklikten koparak, yeni gerçeklikler oluşturma gücüne sahip olurlar. Bu sebepten, gerçeği yeniden ürettiği ya da onun yerini aldığ1 kadar, düşünce yaratma açısından da önemli hâle gelirler (Burnett, 2012: 24). Önce duyguları belirler, sonra bu duyguları düşünceye dönüştürürler (Mitry, 1989: 73). Hatta bir adım öteye geçerek, imgelerin toplumsal gerçekliği inşa edebileceği söylenebilir (Bourdieu, 1990: 134). Bu tür bir yaklaşım, imgelerin gerçeklikle sadece temsil yönünden ilişkisi olduğunu söylemekten çok daha değerli ve kapsayıcıdır. Gerçekten de imge olmayanı var kılabilir; fakat bunu saf temsil olarak görmekten uzaklaşmak gerekir (Yücel, 2013: 16; 19). İmgeler sadece temsil değil, bilginin referans noktalarıdır (Burnett, 2012: 19). Dahası, günümüzde artık her türlü bilginin imgesi de talep edilebilmektedir (Baker, 2012: 21). İmgenin yöneldiği zihin(ler)deki gerçeklikler bu talepten beslenir. Böylece imgeler kendi özgün gerçekliklerini sağlamanın yolunu bulmuş olur (Marin, 2013: 12). Dolayısıyla gerçek olmasalar da gösterdiklerinden çok daha gerçek gibi algılanabilir (Berger, 2012: 10). Bu bir gerçeklik yanılsamasıdır ve bu yanılsamanın en iyi örneklerinden biri, Renè Magritte'in Ceci n'est pus une pipe adlı tablosudur. Magritte bu tabloda bir pipo resmetmiş ve altına "Ceci n'est pus une pipe (Bu bir pipo değildir)" yazmıştır. Magritte oldukça haklıdır, gördüğümüz sadece bir piponun imgesidir (Foucault, 2013: 31). Ayrıca buradaki pipo imgesi tek bir pipoyu temsil ettiğinden, sadece gösterdiğinin imgesidir. Yine de fotografik imgeyle ikonik imgeyi farklı düşünmek gerekir. İkonik imgeler aynı şeyi temsil etme potansiyeline sahipken, fotografik imgeler daha özneldir. Bununla birlikte, imgeyi gösterdiği üzerinden genelleyen ve ona gerçeklik atfeden, son kertede insan zihnidir. Magritte'in tablosunda olduğu gibi, imgenin yanına eklenen söylem ise gerçekliği bir derece daha değiştirebilir. Böylece imge ve söylemin birlikte hareket etmesinin, tek başlarına hareket etmesinden daha yoğun şekilde gerçeğe etki edeceği anlaşılır. Bu etkide imge-söyleme maruz kalan kişinin verdiği düşünsel tepki önemlidir; çünkü belirli bir şey hakkında zihninde hiçbir gerçeklik bulunmayan kişiye sunulan imge, söylemle birleştiğinde, kişinin zihninde saf imgeden daha yoğun bir gerçeklik oluşturacaktır.

Görüldügüü üzere, imge ve gerçeklik ilişkisi açısından; imgenin gerçeği yansıtma, üretme, yeniden üretme ve değiştirme potansiyeli bulunmaktadır. Asıl önemli olan ise imgenin gerçeği ne şekilde ürettiğidir. Üretilen bu gerçeklik, var olanı değil, var olmayanı kasteder. Var olanı üretmek, imgenin yeniden üretim gücüne vurgu yapar. Bu açıdan Platon'un (2011: 336-340) görüşlerine başvurmak gerekir. Ona göre, Tanrının yarattığı ile marangozun zanaatının ve ressamın sanatının gerçeklikleri birbirinden ayrılır. Saf gerçek, Tanrının yarattığıdır. Marangozun zanaatı, Tanrının yarattığından bir derece uzakken; ressamın sanatı, iki kez uzaklaşmış olur. Sonuçta Tanrının yarattığı gerçekliğe yaklaşan imgeler, zihin için çok daha fazla gerçek kabul edilecektir. Sinemasal hareketli imgeler bu yönüyle bize bir çıkış yolu sunabilir; çünkü Cavell'in (1979: 105) de belirttiği gibi, sinema gerçeklik resimlerinin en iyi şekilde düzenlenmesini sağlayan araçtır. Sinema, zaman ve mekânsal gerçekliğe en yakın olabilen hatta onu aşabilme gücünü elinde bulunduran tek sanattır. Şentürk'ün (2011: 78) de vurguladığı üzere, sinemaya kadar olan sanatlar mekânsal hareketi mümkün kılarken, ilk defa sinema aracılığıyla zamansal hareket ve zamansal gerçekliğin oynanabilirliği seyirciye bahşedilmiştir. 
Sinemanın gerçekliğe etkisi yadsınamaz. Ayrıca sinema sadece hareketli imgelerle değil, söylem ve sesler aracılığıyla da gerçekliği yoğun şekilde etkiler. Dolayısıyla sinemanın gerçekliğe etkisinde imge, söylem ve ses olmak üzere üç temel kod belirlemek mümkündür. Filmler, bu kodları karakter, zaman, mekân, kurgu, 1şık, renk, kamera, müzik, söylem (sözlüyazılı dil olarak) ve öykü sayesinde şekillendirir. Tüm bu kodlar ve alt kodlar, bir bütün olarak sinema paradigmasını oluştururken hem imge, ses ve söylemin gerçekliğini hem de mutlak şekilde kabul edilen hakikatleri etkileyebilir.

Sinema, teknolojik gelişmelere bağlı olarak, bir yanılsama üretme aracı olmaktan uzaklaşmıştır. Böylece imge, sinema sayesinde kusursuzlaşma imkânı bulabilmiştir. Hatta Baudrillard'a (2010: 29-30) uygun şekilde imgenin gerçekliğinin, yanılsamanın da gerçek kabul edilmesinin yolunu açtığı düşünülebilir. Bu açıdan Morin (2005: 169), sinemayı dünyanın tüm imgelerini barındıran büyüleyici bir rahme benzetirken, onun hem sihirli hem de gerçekçi yönüne dikkat çeker. Yani sinemasal imgeler, aslında 'sihirli gerçeklikler' olarak akıp gitmektedir. Bu yönüyle sinema, sihir ve gerçeğin başka hiçbir sanatta iç içe geçemeyeceği kadar özgündür.

Sinemanın gerçeklikle ilişkisi tarih sahnesine çıktığ1 ilk günden beri devam etmiştir. Dışavurumculuk, Şairane Gerçekçilik, Yeni Gerçekçilik, Yeni Dalga, Yeni Sinema, Özgür Sinema ya da Deneysel Sinema gibi akımlar, filmlerin gerçeği nasıl ortaya koyduğu veya koyması gerektiği üzerine şekillenmiştir. Eisenstein, farklı görüntüler yardımıyla izleyicide oluşturulacak 'şok' etkisiyle yeni ve zihinsel bir gerçeklik yaratmayı amaçlarken; Vertov'un 'sine-göz' ü, gerçeği olduğu hâliyle göstermeyi hedeflemiştir. Benzer şekilde Bazin, sinemanın önemli bir gerçekçilik sanatı olduğunu savunabilmiştir. Yine Pezzella'ya (2006: 43) göre 'gösteri sineması', gerçekliğin simülakrıyla özdeşleşme yaratırken; 'eleştirel sinema', görüntünün gerçekliği ve uzaklığını hatırlatma derdine düşmüştür. Tüm bu akımlar, kuramlar ya da düşünceler, sinemanın gerçeklikle ilişkisinin ne kadar kaçınılmaz olduğunu ortaya koyar. Bu sebepten Diken ve Laustsen (2011: 21), "sinema hayattır ve hayat da sinemadır, ikisi de birbirinin hakikatini anlatır" derken, oldukça haklı gözükür.

Sinema sadece gerçeklikle ilişki içinde olmakla kalmayıp, gerçeklik üretebilme yetisine de sahiptir. Örneğin Kellner (2013: 29), filmlerin çeşitli görme biçimleri yarattığ1 gibi, geleneksel görme biçimlerini ya yeniden ürettiğini ya da daha önce bazı şeylerin hiç görülmediği şekilde görülmesine destek olduğunu söyler. Ona göre, filmler sadece gerçeklik sunmaktan öte, belirli gerçeklikler yaratabilir ve geleceğe yönelik olaylar üzerine tahminler yürüterek yeni vizyonlar sunabilir. Benzer şekilde sinemayı bir düşünce sistemi olarak gören Frampton'a (2013: 31) göre, filmler zihinsel gerçeklikleri değiştirebilir ve bunu kendi öznel yapılarıyla sağlar. Dahası Faure'nin (2006: 74) belirtiği şekliyle, dünyanın gerçek yüzü en iyi şekilde sinema aracılığıyla tanınabilir. Böylece yazgılar, evrensel derinlikler ya da hafıza ötesi oluşumlara dair değerler filmler sayesinde edinilir. Tüm bu örneklerde de dikkat edildiği üzere, gerçeklik üretiminde ya filmlerden genel olarak bahsedilmekte ya da bunu oluşturan yapının ne olduğuna dair bir sinemasal kavramsallaştırma arayışına başvurulmamaktadır. Dolayısıyla bu duruma bir çözüm olarak kavramsallaştırılmaya çalışılan sinedigmayı açıklamak önemlidir.

\section{Sinedigma}

Öz şekilde, sinema paradigmasındaki herhangi bir değer (kod/altkod), herhangi bir gerçekliği (zihinsel veya toplumsal) değiştirdiği ya da özünden yeniden ürettiği ve bu gerçeklik varlığını koruduğu sürece, gerçekliğe etki eden her bir sinema kodu/altkodu 'sinedigma' olarak adlandırılabilir.

Sinema paradigmasındaki bir kod ya da alt kodun sinedigma şeklinde anılabilmesi için, iki temel durumu sağlaması gerekmektedir. İlk olarak, bir şeye ait gerçekliğin sinema 
paradigmasındaki kod ya da alt kodlar aracılığıla üretilmiş ya da değiştirilmiş olması gerekmektedir. Yani kişi, kurum, sinema dişındaki sanat dalları, doğa ve hareketli imge barındırmayan kitle iletişim araçları (gazete, dergi vs.) gibi kaynaklar aracılığıyla üretilen, değiştirilen veya özünden yeniden doğan gerçeklik, sinedigmanın alanı dışındadır. Bununla birlikte televizyon filmleri, diziler, video klipler veya reklamların da temelde sinema paradigmasından yararlanmasından ötürü, sinedigma(lar) barındırma ihtimali olduğunu düşünmek gerekir. İkincisi, insanların sinemasal kodlar aracilığıyla yeniden üretilen, değiştirilen ya da özünden doğan bir gerçekliği algısal yönden kabul etmiş olması gerekmektedir.

Sinedigmanın çıkış noktasını, Baudrillard'ın imge ve gerçek arasındaki ilişki üzerine görüşleri oluşturur. Baudrillard (2011: 44), çağın temel hastalığını gerçeğin yeniden ve yeniden üretimi olarak görür; fakat bu gerçek, simüle edilmiş bir gerçektir. Baudrillard (2006: 120), “her şey gerçektir" gibi bir söylemin insanlarca onaylandığını; ancak "her şey bir simülasyondur, sizin yaşadığınız gerçeklikler sadece üretilen gerçekliklerdir" denildiğindeyse, insanların alay edeceğini belirtir. Sinedigma, böyle bir vurguyu kendi bünyesinde barındırmaya çalışır ve sadece sinemadan hareket etmeyi amaçlar. Sinedigma, insanların simülasyon evreninden edindiği gerçekliklerin sinema kısmını kapsamakla beraber, imgenin yanına ses ve söylem ögelerini de koyar. Her ne kadar Metz (2012: 96), sadece hareketli imgenin sinematografik olduğunu; ses, müzik ve sözün ise sinemaya özgü olmadığını vurgulasa bile, sinema tüm bu ögelerin kullanımında bir değişikliğe sebep olarak ses, müzik ve sözü kendi değerler sisteminin bütününü işaret eden sinema paradigmasının içine yerleştirebilmektedir. Neticede sinedigma; karakter, zaman, mekân, kurgu, 1şık, renk, kamera, ses, müzik, söylem (sözlü-yazılı dil olarak), öykü gibi sinema paradigmasındaki kodlar ve bunların alt kodları aracılığıla oluşturulan gerçekliklerin, temas ettiği zihinler için inandırıcı olmasıyla ortaya çıkar. Sinema yoluyla elde edilen gerçekliğe karşı inanç ortadan kalktığında, sinedigma da anlamını yitirir. Dolayısıyla sinedigmanın varlığı, sinema paradigması aracılığılyla sunulan gerçekliklere inanmak ve bu gerçekliklerle ilgili bilgilere sahip olmamak ya da mevcut bilgileri dışlamakla sağlanır. Örneğin Türkçe bir belgesel izleyen ve anadili yine Türkçe olan bir seyircinin penguen, timsah ve kaplana dair hiçbir bilgiye sahip olmadığını varsayalım. Belgeselde 'penguen' yerine 'kaplan' ifadesi kullanıldığında, seyircinin inanacağı ve penguen olarak bilinen canlıya karşı oluşturduğu gerçeklik, kaplan olacaktır. Böylece bu seyirci için penguen imgesi ve penguen söylemindeki gerçeklik bağlamından koparılmış ve kaplan gerçekliğine taşınmış olur. Benzer şekilde, penguen imgesine eşlik eden ses montaj yoluşla bir timsah sesiyle değiştirildiğinde, aynı seyirci daha önce söylem yoluyla kaplan olarak kabul ettiği penguenin sesini de timsah sesi sanacaktır.

Yukarıdaki örnekte de aktarıldığı üzere, bir penguene timsah sesi eklemek sinema paradigmasından yararlanılarak başarılacak bir şeydir. Yani sinema aracılığıyla seyircinin zihninde özünden yeniden doğan bir gerçeklik oluşturulabilir. Penguen imgesine eklemlenen kaplan söylemi ve timsah sesi, penguen için bambaşka bir gerçekliği mümkün kılar ve bunu sağlayan şey, sinedigmadır. Bu gerçekliğin genel olarak kabul edilen gerçeklerle uyuşması veya doğru olup olmaması önemli değildir. Seyirci, penguen olarak bilinen canlının kaplan olduğuna ve timsah sesi çıkardığına inandığı sürece, sinedigmatik etki oluşmuş ve o seyirci için penguenin, penguen olduğu gerçeği dişlanmış olur. Bu açıdan Frampton (2013: 241), filmsel gerçekliği seyircinin kendi gerçekliği kabul ettiğini söylerken haklıdır; fakat bu gerçekliğin "bizimki gibi olmadığını biliriz" derken yanılır. Seyirci, filmsel gerçeklikleri kabul edebilir; kendi gerçeği olarak yaşayabilir. Böylece sinedigmaların ortaya çıkması için yeterli zemin hazırlanmış olur. Mesela karanlık sokaklarda suçun mağduru olabileceği inancını sinema paradigmasından yararlanan herhangi bir film, dizi, reklam, video klip ya da video görüntüden 
elde eden seyirci için bu gerçeklik, sinedigmatiktir ${ }^{1}$. Yine Benjamin' in (2002: 64) belirttiği gibi, sinemasal bir değer olan 'ağır çekim' ile seyirci, bir hareketin normalde asla fark edemeyeceği ayrıntılarına kadar olan gerçekliğinin bilgisine ulaşabilir. Önemli olan, herhangi bir sinemasal kod ya da kodlar aracıllğıyla üretilen ya da değiştirilen gerçekliğin kabul görmesidir. Zihinsel olarak kabul gören gerçeklik daha sonra herhangi bir kaynak tarafından bozularak veya yeni bir gerçekliğe taşınarak zihinden dışlandığında, sinedigmatik yapı çöker.

Sinedigmayı, filmsel ideolojilerle karıştırmamak gerekir. Bu yönden McGowan (2014: 197), ideolojilerin özneler tarafından gerçek bir varoluş şeklinde tanındığ 1 için etkin olduğuna vurgu yapar. Dolayısıyla özneler, ideolojilerin gerçekliğine inanır. Bu yönden, sinedigma kavramının ideolojiyle ilişkili olduğu düşünülebilir; fakat genel anlamda sinedigmalar, ideolojilerin sinema ayağını da bünyesinde barındıran farklı bir kavram olarak değerlendirilmelidir. Sinemasal içerik ya da biçimsel değerin hangisi ya da hangileriyle üretilirse üretilsin, filmsel ideolojiler gerçekliği kabul edildiği sürece sinedigmadır. Bununla birlikte, sinedigmaların hepsi ideolojik değildir. Az önceki örnekte de olduğu gibi, penguen imgesini kaplan söylemiyle birleştirerek izleyicide farklı bir gerçeklik yaratılması ideolojik değildir. Sadece doğal gerçekliğe yapılan müdahaleyle, bizzat gerçeğin bozulması ve seyirciye inanabileceği yeni bir gerçeklik sunulmasıdır. Yine filmler belirli bir gerçekliğin yeniden üretimi konusunda ideolojik sayılabilir; fakat ortada hiç var olmayan bir gerçeği sunması açısından aynı zamanda sinedigmatik hâle gelir.

Bir seyirci Frampton'un (2013: 174) belirttiği gibi, Mullholand Çıkmazı (Mullholand Dr., David Lynch, 2001) filminin imgeleriyle sersemleyebilir, seslerinden rahatsiz olabilir ve sonuçta yeni bir gerçekliğe inanabilir. Onu etkileyerek belirli bir şey üzerindeki gerçeklik algısını değiştiren ya da zihninde yeni bir gerçeklik yaratan bu imge ve seslerin her biri ayrı sinedigmalardır. Bu durumu, Maccannel'in (2014: 94-95) ortaya koyduğu örnek üzerinden daha net şekilde değerlendirmek mümkündür. Onun aktardığına göre, hukuk profesörü Francis Nevis, Korku Burnu (Cape Fear, J. Lee Thompson, 1962) filmini hukuk fakültesindeki derslerine konu eder. Filmi oldukça etkili bulan Nevis, Scorcese tarafından 1991'de yeniden çekilen versiyonun ise birçok hukuksal yanlışlikla dolu olduğuna vurgu yapar. Görüldüğü üzere, hukuk bilgisi olan bir kişi, filmdeki hukukla ilgili gerçeklikleri olduğu gibi kabullenmeyebilir. Aslında bu iki film, gerçeği farklı şekilde ele almıştır. İlk filmdeki hukuka uygun olan gerçeklik, bazı seyircilerin zihninde de hukuk üzerine gerçeklikler oluşturacaktır. İkinci filmdeki hukuka uygun olmayan filmsel gerçeklik de yine bazı seyirciler için hukuksal yönden bu yanlışların sorgulanmadan kabul edilmesine neden olabilir. Dolayısıyla hukuksal açıdan aynı durumun hem doğru hem yanlış yönü farklı seyirciler açısından gerçektir. Her iki filmde de doğru ya da yanlış olması fark etmeksizin gerçekliği oluşturan her türlü kod veya altkod, sunulan gerçekliğe inanan seyirciler için, aynı zamanda birer sinedigmadır.

Baudrillard (2011: 75), Son Gösteri (The Last Picture Show, Peter Bogdanovich, 1971) filmini izlerken 1950'de çekilen bir film olduğunu düşündüğünü; ancak 1970'lerde çekildiğini öğrenince şaşkınlık içerisinde kaldığını aktarmaktadır. Aslında filmin 1950'lere ait olduğu gerçekliğine ona inandıran filmdeki tüm kodlar ya da alt kodlar, birer sinedigma olarak düşünülebilir. Baudrillard, filmin 1970'de çekildiği gerçekliğine ulaştığ1 ve zihinsel olarak bu gerçeği kabul ettiğinde ise ona filmin 1950'de çekildiğine inandıran tüm kodların geçerliliği son bulur ve böylece sinedigmatik yapı çökmüş olur.

Sinedigmalar farklı şekillerde sınıflandırılabilir. Mesela film türleri açısından; 'bilimkurgu sinedimaları (ufo, marslılar, üçüncü boyut vb.)', 'korku sinedigmaları (vampir, zombi, hayalet vb.)', 'western sinedimaları (koyboy, düello, çiftlik)' ya da filmsel araçlar açısından; 'zaman

\footnotetext{
${ }^{1}$ Bu çalışmada sinema filmleri üzerinden bir değerlendirme yapılmaktadır. Sinema paradigmasından yararlanan televizyon filmi, dizi, reklam, video klip ya da video görüntüdeki sinedigmalar bu çalışmanın konusu dışında olduğundan değerlendirmeye alınmamıştır.
} 
sinedigmaları (gündüz, gece vb.)', 'karakter sinedigmaları (zenci, kadın, köpek vb.)', 'ses sinedigmaları (kuş, fil, tren vb.)' gibi bir sınıflandırma yapmak mümkündür. Örneğin Dünyalar Savaşı (War of the Worlds, Steven Spielberg, 2005) filmindeki 'istila' gerçekliğine inanan bir seyircinin, bu filmden sonra uzaylı istilasına karşı sığınak yapmaya çalışması, tam anlamıyla seyircinin zihninde işleyen bir bilimkurgu sinedigmasının varlığını işaret etmektedir. Onu uzaylı istilasına inandıran şey, baştan sona tüm film değil, filmdeki uzaylılardır. Dolayısıyla burada karakter (uzaylı) kodu, kendi gerçekliğini inandırdığı tüm seyirciler için, aynı zamanda uzaylı sinedigması olarak kabul edilebilir. Yine çocukların oyunlarında yer alan 'kovboyculuk', tam da western sinedigmalarının etkisiyle oluşmuş bir gerçeklik sayılabilir. Özellikle bu oyundaki 'düello ${ }^{2 \prime}$ olgusu, western filmlerindeki düello kodlarının gerçekliğiyle kabul edilir ve çocukların oyunlarında kullanılır.

Sinedigmalar sadece zihinsel gerçeklikler üretmez ya da mevcut gerçeklikler yerine yenilerinin getirilmesini sağlamaz. Sinedigmalar aynı zamanda kimi seyirciler için, eylem aşamasında da kabul gören gerçeklikler olabilir. Böylece seyirci, sinedigmaların gerçekliğini zihinsel olarak kabul ettiği gibi, kendi yaşantısına da uygulayabilir. Bu yönüyle zihinsel gerçekliği eylemsel gerçekliğe (tutum ve davranışa) dönüştürebilen sinedigmaları, 'eylem sinedigmaları' şeklinde düşünmek mümkün hâle gelir. Bu sefer ortaya çıkan durum zihinsel gerçeklik üretimi değil, bizzat zihin yaratımıdır. Örneğin Gabbard ve Gabbard (2009: 284294), Guguk Kuşu (One Flew Over the Cuckoo's Nest, Milos Forman, 1975) filmini izleyen bir hastanın, filmdeki EKT (elektrokonvulsif terapi)'nin ceza amaçlı kullanılmasından etkilenerek daha önce EKT için verdiği onayı geri çektiğini belirtir. Yine daha önce yattığı hastanenin güvenli olduğunu düşünen bir hasta, Frances (Graeme Clifford, 1982) filminde hastaneye kaçak sokulan denizcilerin, diğer hastalara tecavüz ettiği sahneden sonra sinemayı terk etmiş ve hastanenin güvenli bir yer olmadığını düşünmeye başlamıştır. Hatta Laing' in (2012: 152-153) aktardığına göre şizoid bir kız, Sonsuz Sokaklar (La Strada, Federico Fellini, 1954) filmindeki 'zincirkıran' adlı karakterin satın aldığı kızın hayatını kendi hayatıyla özdeşleştirmiştir. Yani filmdeki kızın gerçekliği, şizoid kızın gerçekliği hâline gelmiştir. Bu örneklerden de anlaşıldığ1 üzere, filmlerdeki bazı kodlar, kimi seyircilerin gerçekliklerini eylem düzeyine geçecek kadar etkileyebilmektedir. Bu açıdan Guguk Kuşu filmini izleyen seyircinin EKT'ye karşı mevcut gerçekliğini, Frances filmini izleyen seyircinin denizcilere ve hastaneye karşı tutum ve davranışını ya da Sonsuz Sokaklar filmini izleyen kızın bizzat yaşantısını değiştiren tüm filmsel kodlar, birer eylem sinedigması olarak düşünülebilir.

\section{Toplumsal Gerçeklik ve Seyrin Kültüründe Sinedigmaların Rolü}

Filmler aracılığılyla henüz toplumsal olarak gerçekleşmemiş durumlara karşı bir alg1 oluşturulabilir ya da soyut kavramlara dair gerçeklikler aktarılabilir. Örneğin aşka dair gerçeklik sinemasal imgeler aracılığıyla sunularak seyircide de bu soyut kavram hakkında bir gerçeklik oluşturabilir. Sinema bunu diğer sanatların asla başaramayacağı kadar etkili şekilde yapar. Dolayısıyla sinemanın gerçekliği değil, gerçekliğin sinemayı yansıtması gibi bir durum ortaya çıkabilir (Diken ve Laustsen, 2011: 19-20). Dahası Baudrillard'ın (2005: 124) da vurguladığı gibi, sinemanın gerçeği şekillendirdiği hatta giderek onun yerini aldığ1 söylenebilir. Bu görüş, filmlerin toplumsal gerçeği kuşatma altına alacak kadar güçlü olduğunu düşündürür. Doctorow'un (2000: 190) City of God adlı eserinde tam da bu duruma uygun şekilde, filmler insanların hislerine, düşüncelerine ve zihinlerine hükmeden zararlı yaşam formları olarak betimlenir. Bu yönüyle sinema toplumsal yapıyı ele geçirmiş gibi görünür; ancak bu fazla distopik bir düşüncedir. Gerçek anlamda sinema Bèla Balàzs'in (1970: 17)

\footnotetext{
${ }^{2}$ Çocukların kovboyculuk oyunlarındaki bu olguda oyuncak silahlar kullanıldığı gibi, sopalar da silah yerine geçebilir. Çocuklar western sinedigmalarından hareketle, düellonun gerçekliğini kabul eder ve bu gerçekliğe uygun şekilde sırt sırta verir, birkaç adım sayar (bu sayı genelde 3 ya da 10'dur) ve dönüp birbirlerine hayali şekilde de olsa ateş eder. Ateş ederken ağızlarından çıkardıkları silah sesinin gerçekliği bile, filmlerde duydukları sesin gerçekliğine uygun olabilmektedir.
} 
değindiği hâliyle, halk üzerinde diğer hiçbir sanatın başaramayacağı kadar etkin bir sanat dalıdır; toplumu kuşatmaktan ziyade, şekillendirme yönünden etkin bir sanat.

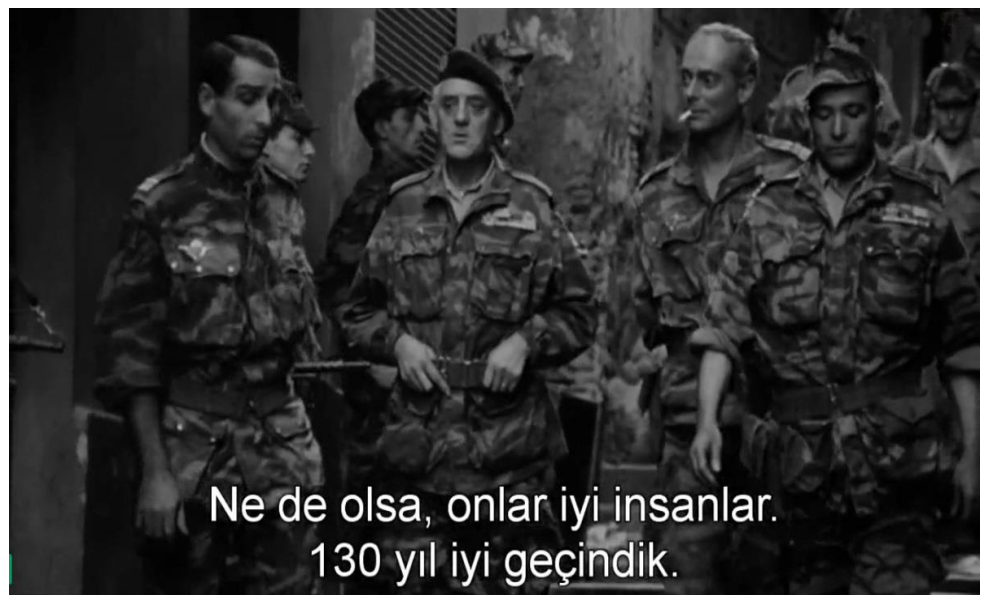

Görsel 1: Cezayir Savaşı

Filmler tarihsel olayları, karakterleri, kültürel normları ve daha birçok toplumsal durumu şekillendirebilir (Kellner, 2013: 30). Örneğin Cezayir Savaşı (La battaglia di Algeri, Gillo Pontecorvo, 1966) filminde, Fransız paraşüttçüler Ulusal Kurtuluş Cephesi hücrelerini imha ettikten sonra, bir asker Cezayir hakkında şöyle der: "Ne de olsa, onlar iyi insanlar. 130 yıl iyi geçindik. Neden bu devam etmesin?" Bu söylem, Fransa ile Cezayir arasındaki ilişkiye dair bir gerçeklik ortaya koyar. Filmin 1960'1n Cezayir'ini göstermesi ve Fransa'nın, Cezayir'i ilk olarak 1830'da 'işgal ettiği' düşünüldüğünde, bu söylemdeki 130 yıllık ilişkinin gerçekliği doğrulanabilir. Wayne'nin (2009: 25) de vurguladığı gibi, ilk aşamada bu filmsel söylem seyirci için karşı koyul(a)maz bir gerçeği yansıtır. Asıl gerçekliğe ve tarihe bakıldığında ise bahsedilen 130 yılın işgal altında ve acımasızca geçen bir süreç olduğu anlaşılacaktır; çünkü Fanon'un (2007: 61) belirttiği şekliyle, 1945'te sadece Setif'te 45 bin Cezayirli, Fransızlar tarafından katledilmiştir.

Cezayir Savaşı, filmlerin gerçekleri istediği yönde şekillendirebilme kudretini gösteren örneklerden sadece biridir. Ryan ve Kellner'ın (2010: 18) da belirttiği gibi, filmler herhangi bir durumu olduğu şekilde yansıtmakla yetinmez, seyirciye çeşitli bakış açıları sunar. Cezayir Savaşı'nda sunulan ideolojik bakış açısı, Fransa'nın barışçıl bir politikayla Cezayir'e yaklaştığı gibi bir gerçeğe seyirciyi inandırabilir. Özellikle zihnini asıl gerçekliklere kapatan ve filmlerin sunduğu kadarını algilayan seyirci için bu örnekteki askerin söylemi, bizzat ölen binlerce Cezayirlinin gerçekliği yerine geçecek kadar güçlü bir etki yaratacaktır. Zaten aksine dair bir yarg1 ya da bilgi bulunmadıkça, Diken ve Lautsen'in (2011: 24) düşüncelerinde de olduğu gibi, gerçek sadece sunulduğu şekliyle kabul edilecektir. Dolayısıyla seyircinin zihni yerine geçen 'film-zihin' ve onun yerine düşünerek seyircinin de kendi gibi düşünmesini sağlayan bir 'film-düşünce' den bahsetmek mümkün hâle gelir. Bu yönden Frampton (2013: 149), filmzihin olarak belirlediği filmsel düşüncenin seyirciden daha iyi düşünebildiğini ifade eder. Ona göre, filmsel araçlar olmadan ulaşıl(a)maz olan gerçekliklere filmler sayesinde ulaşılabilir. Hatta filmler hiç olmayan gerçeklikler de üretilebilir. Bunu sağlayan film-zihin insan zihnine benzese de farklı yapıdadır. Frampton'un bu düşünceleri, filmler sayesinde düşüncelerin etki altına alınabileceğini savunan Deleuze'ü (1997: 187-188) hatırlatır. Ona göre bu, 'zamanimaj' dan çok daha fazla 'hareket-imaj' ile ilişkilidir.

Deleuze'ün görüşlerine uygun bir tavırla, sinedigmaların bazı gerçekliklerin zihinlere yerleştirilebilmesi, dolaylı olarak 'hareket-imaj' temelli olan Hollywood üzerinden düşünce aktarımına devam edilmesinin yolunu sunar. Zaten Hollywood’un gerçeklik üretimindeki 
payı, daha geniş kitlelere ulaşabilme gücüne bağlı şekilde, diğer ülke sinemalarından çok daha fazladır (Monaco, 2010: 250).

Hollywood filmleri, toplumsal gerçekliğin belirli şekillerde inşa edilmesine zemin hazırlar (Ryan ve Kellner, 2010: 38). Bu açıdan bakıldığında, filmler ideolojik yapılar olarak görülebilir; fakat Hollywood filmleri aynı zamanda toplumsal gerçekliğe etki eden pek çok sinedigmatik yapıyı bünyesinde barındırır. Kitlesel bir etkiyle, herhangi bir durum üzerine gerçeklikler oluşturabilir. Örneğin Kakınç'a (1993: 44) göre, Ben Bir Pranga Kaçă̆ıyım (I Am a Fugitive From a Chain Gang, Mervyn LeRoy, 1932) adlı filmin başkarakteri Paul Muni'nin oyunculuğu insanları büyülemekle kalmamış, Amerika' da uygulanan cezalar içinde 'prangaya vurulma' cezasının kaldırılmasına katkıda bulunmuştur. Bir toplumsal gerçeklik olarak pranga cezasının kaldırılması üzerindeki etki, tüm bir sinema evrenine ya da pek çok filme bağlanamayacağı gibi, bahsi geçen filmin tümüyle de ilişkilendirilemez. Yine de toplumsal bir gerçeklik olarak pranga cezasının kaldırılmasında Paul Muni'nin de payı olduğu düşünüldüğünde, ortaya çıkan sinedigmatik yapı Şekil 1 ile gösterilebilir.

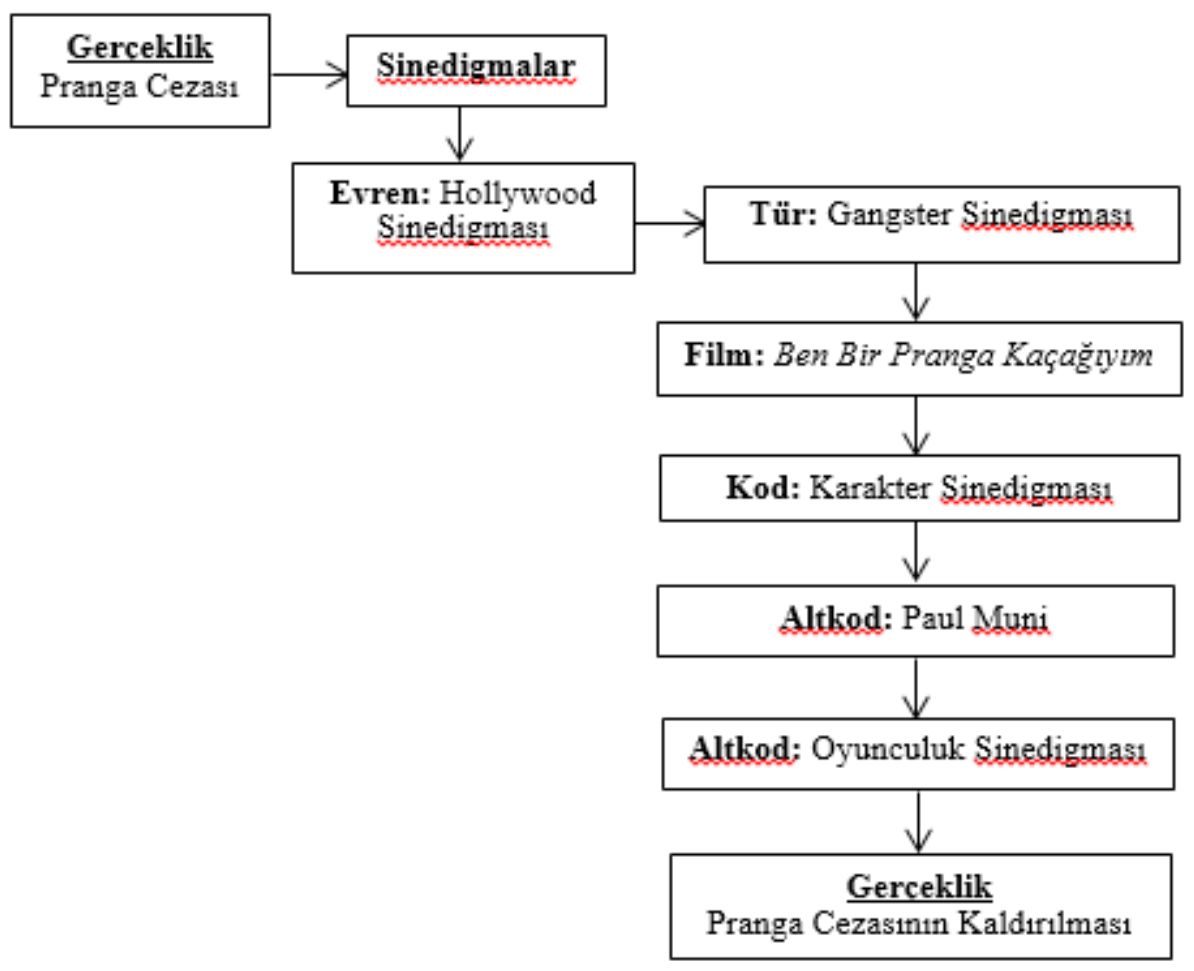

Şekil 1: Amerika' da Pranga Cezasını Etkileyen Sinedigmatik Yapı

Şekil 1'de herhangi bir toplumsal gerçeklik içerisinden Amerika'daki 'pranga cezası' gerçekliği ele alınmıştır. Bu gerçeklik, sinema paradigmasındaki değerler aracılığıyla şekillendirilerek, sosyal ve siyasi gelişmelerin de yardımıyla, yerini 'pranga cezasının kaldırılması' gerçekliğine bırakmıştır. Yani toplumsal bir gerçeklik olarak pranga cezasının kaldırılmasında genelden özele doğru işleyen sinedigmatik yapının varlığı kendini hissettirmektedir. Genel anlamda filmde karakterlerin çektiği acı, maruz kaldığ1 şiddet, temizlenme şekilleri, yemekleri, tuvalet ihtiyaçlarını gidermeleri vs. ortaya koyulması dikkat çeker. Bu görüntülere eşlik eden kamera, özellikle yakın planlarla etkinin gücünü arttırır. Ancak pranga cezası gerçekliğinden pranga cezasının kaldırılması gerçekliğine geçişi etkileyen temel sinedigmanın Paul Muni'nin mimikleri, jestleri, bakışları, kararlılığı vs. özelliklerinin tümünü içinde barındıran oyunculuğuyla ilişkili olduğu düşünülebilir. Buradan hareketle, 
herhangi bir gerçekliğe etki açısından sinedigmatik yapının daha geniş ya da daha dar şekilde ortaya koyulabileceği anlaşılmaktadır. Önemli olan, yeni bir toplumsal gerçeklik üreten ya da mevcut toplumsal gerçekliğin değişmesine etki eden sinedigmaların hangisi olduğunu doğru şekilde belirlemektir.

Filmler toplumsal bir gerçekliğe dair birden fazla değerin şekillenmesine etki edebilir. Böyle bir durumda tek bir sinedigmadan ziyade, birden fazla sinedigmanın varlığından bahsetmek olasıdır. Örneğin Hollywood filmleri psikiyatri üzerine yeni değerler üreterek toplumsal gerçeklikleri değiştirebilir. Bu açıdan Gabbard ve Gabbard (2009: 73, 143), filmlerin insanlar üzerindeki etkisiyle, 1950 'lere gelindiğinde orta-üst sınıfın divana uzanma fırsatını bekler hâle geldiğini belirtmektedir. Aslında psikoterapide 'divana uzanma' şeklinde bir gerçeklik olmadığı gibi, tedavi de genelde ilaçla yapılır. Yine EKT tedavisi ise filmlerdegenellikle bir cezalandırma yöntemi olarak sunulmaktadır. Psikiyatriye ait bu toplumsal gerçekliklerin aslında zihinsel yanılsamalar olduğu, bir psikiyatri kliniğine gidilince anlaşılabilir. Dolayısıyla tüm bu yanılsamalı gerçekliği oluşturan kodlar, sunulan gerçeklikleri kabul eden kitleler için birer sinedimadır. Psikiyatriyi kullanan filmlerin, divana uzanma fırsatı bekleyen koca bir toplumsal sınıf yaratma gücü, aslında sinedigmaların bir çeşit kültür oluşturabileceği ve bu kültürü yayabileceğini de göstermektedir.

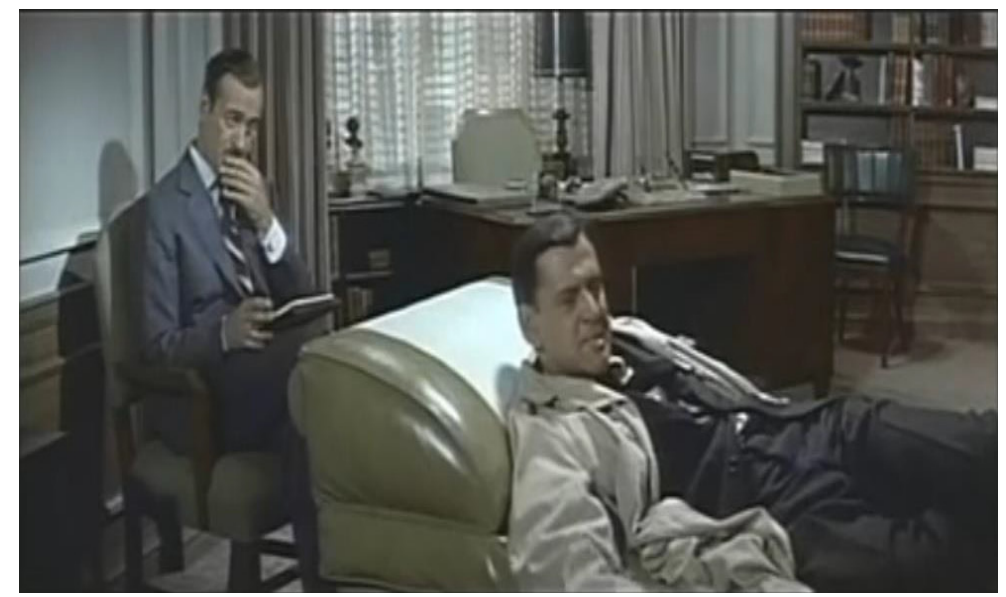

Görsel 2: Psikiyatrist ve hastalarına yer veren Oh, Men! Oh, Women! (Nunnally Johnson, 1957)'da 'divana uzanma' kodu

\section{Seyir Kültürründen Seyrin Kültürüne Sinedigmalarn Rolü}

Sinemanın kültürle üç farklı açıdan ilişki içinde olduğu söylenebilir: Üretim, izlenme ve etki. Üretim açısından; filmler kültürel ürünlerdir ve üreticilerinin kültürel değerleriyle şekillenebilir. İzlenme açısından; filmler farklı kültürel değerlere sahip ülkelerde, farklı şekillerde izlenebilir ve bu izleme kültürü zamanla değişebilir. Etki açısından; filmler üretildikleri toplumun değerleri ve izlenme pratiklerinin desteğiyle, toplumların kültürel değerlerini etkileyebilir. Yani üretim ve izlenme kültürü, bizzat izlenim sonucu oluşan kültürü etkilemektedir. Dolayısıyla kültürle ilişkisi bakımından ortaya koyulan bu üç temel varsayım, filmlerin 'üretim kültürü', 'seyir kültürü' ve 'seyrin kültürü' bakımından değerlendirilebileceğini göstermektedir.

Öncelikle filmlerin üretildikleri kültürden bağımsız düşünülemeyeceğini vurgulamak gerekir. Her film üretildiği toplumun bağlı olduğu kültürel kodları da bünyesinde barındırır. Dolayısıyla tarihsel süreçteki toplumsal değişimlerin filmsel kültüre de etki edeceği ortadadır. Üretim tarzından dağıtım aşamasına kadar uzanan toplumsal, ekonomik ve teknolojik gelişmelerin hepsi, filmler aracılığıyla üretilen ve yayılan kültürel kodları olumlu ya da olumsuz yönde etkileyecektir. Mesela Bordwell ve Thompson'ın (2002: 354) da belirttiği gibi, 
Hollywood filmlerinin küresel pazara yayılmasındaki asıl amaç insanları Amerikalı yapmak değil, dünyaya tüketim kültürünü aşılamaktı. Hollywood ise bu büyük projenin temelini oluşturmuştu. Bu sebepten, Hollywood'un görevi oldukça önemliydi. Aslında Hollywood, bu görevi layıkıyla gerçekleştirdiğini kısa sürede kanıtladı. Kawana'nın (2008: 22) belirttiği şekliyle, henüz 1930'lardaki Amerikan filmleri Japonlar için başka bir kültürün parçası değil, kendi toplumlarının kentsel deneyim ve liberalizm hakkında paylaştığı değerlerin anımsatıcısı durumuna rahatlıkla gelebilmekteydi. Yine ilk dönem film türlerinden olan westernler, Batı'ya ait her şeyi idealize ederek kendisini Amerikalı hissetmek isteyenlere sonsuz olanaklar sunuyordu. Suçlular birer kahraman oluyor, gerçekler göz ardı ediliyor ve toplumlar yepyeni bir gerçekliğe kendini bırakıyordu (Abisel, 1995: 80). Aynı zamanda Hollywood, Doğu'nun yaratılma, yeniden üretilme ve belirli kalıplara sokulmasında Oryantalist bir tavır takınıyordu ve bunu sürdürdü (Kırel, 2012: 419). Dolayısıyla Doğu' ya ait kültürel değerler küresel pazardaki dolaşıma sokulamadığı gibi, Doğu'nun şeytanlaştırılarak Batı'nın kutsanması da Hollywood filmleri aracılığıyla gerçekleştirildi. Tüm bunları sağlayan şey ise aslında sinedigmalardı.

İnsanların belirli bir hayvan, insan, ırk ya da topluma dair gerçekliklerini etkileyebilen sinedigmalar, sanattan mimariye kadar topluma dâhil olan her şeyi de etkisi altına alabilir. Örneğin Türk kültürüne ait gerçeklikleri filmlerde gördüğü kodlardan elde eden Avrupalı bir sanatçı, kendi eserlerinde Türkleri bu gerçekliklere göre tasvir edebilir. Bu tasvir, diğer sanatçıları ve en sonunda sanatçının mensubu olduğu toplumun gerçekliğine etki ederek kültürel yapıda Türklere karşı belirli bir bakış açısı oluşturabilir. En nihayetinde, sanatçının bağlı olduğu toplumda Türkler, filmlerde sunuldukları gerçeklikleriyle var olma durumuyla karşılaşır. Aslında bu örnek, seyrin nasıl bir kültürel etkisi olabileceğini göstermektedir.

Hollywood sinedigmalarının seyrin kültüründe etkili olabilmesi için, filmlerin sadece kültürel ürünler olarak düşünülmesi yeterli değildir. Bu filmlerin yayılması kadar, belirli bir seyir kültürünün oluşturulması da gerekmektedir. Bu açıdan Adorno'nun (2007: 56), seyir sırasındaki izleyici tepkilerinin bir kültür oluşturduğuna yönelik vurguları önemlidir. Ona göre, seyircinin kendisini seyrettiği şeye kaptırması şart değildir. İstenilen kadar dikkatini vermesi, daha önce izlediği filmlerden elde ettiği deneyimlerle kendiliğinden gerçekleşecektir. Seyirci neye güleceğine, ne zaman ağlayacağına, hangi nesneler aracılığıyla korku yaşayacağına alıştırılır. Tüm bu alışkanlıklarıyla film izlemek için salonları dolduran izleyiciyi, karanlık ve gözünün önündeki ışık kaynağından başka yöne bakmasına izin vermeyen büyük film perdesi aynı anda karşılar. Dahası, üç boyutlu filmlerde bakışın gözlük çerçevesinin dışına bile çıkmasına fırsat tanınmaz. Dolayısıyla görüntüler saf gerçeklermiş gibi görünür. Bu '-miş gibilik', seyirciyi gerçeklik ve simulakrı ayırt edemeyecek bir konuma taşır. Ses de benzer şekilde, seyirciyi dış dünyanın diğer tüm seslerine karşı sağır eder (Gültekin, 2018: 12). Tüm bu koşullar sağlandığında, seyir kültüründen seyrin kültürüne doğru geçişin çok daha kolay olacağı düşünülebilir. Yine de Kırel'in (2012: 17) belirttiği gibi, teknolojik gelişmelere bağl1 şekilde, filmlerin heryerdeliğini de hesaba katmak gerekir. Bu seyir deneyimleri de farklı bir seyir kültürü ve buna bağlı olarak seyrin kültürünü oluşturacaktır. Dolayısıyla sinema salonunun yapısı, filmsel gerçekliğin daha etkili şekilde kabul edilmesine yardımcı olurken; teknoloji aracılığıyla sağlanan seyrin heryerdeliği, filmsel gerçekliğin daha fazla kişiye ulaşmasını sağlamaktadır. Bu iki farklı seyir deneyiminin, seyrin kültürüne etki ve yoğunluk açısından farklı katkıları olacaktır. Sinema salonundaki seyir etki açısından; salon dışı seyir ise yoğunluk açısından seyrin kültüründe önemli bir yere sahiptir.

Seyrin kültüründen kasıt, filmlerin nasıl, nerede ve hangi koşullarla izlendiğine ya da bunların tarihsel süreçte nasıl değişkenlik gösterdiğine yönelik bir seyir kültüründen ziyade, bu seyirden sonra geniş kitlelere ait gerçekliklerin nasıl üretilebileceği, değişkenlik gösterebileceği ve bunların ne tür bir kültür oluşturabileceğidir. Bu kültürün oluşmasında sinemanın değil, sinedigmaların payı bulunmaktadır; çünkü seyir kültürü tüm bir sinema deneyiminin toplumsal olarak nasıl gerçekleştiğine vurgu yapar. Seyrin kültürü ise sinema 
aracılığıyla elde edilen kültürü belirtir. Dolayısıyla tüm bir film, baştan sona yeni bir gerçeklik üretmeyeceği ya da mevcut toplumsal gerçekliği değiştirmeyeceği gibi, kültür oluşumuna da tamamen dâhil ol(a)maz. Bunun yerine, kültür oluşumunda özel sinemasal kodlar olan ve toplumsal gerçekliği üreten ya da değiştiren sinedigmalara değinmek anlamlıdır. Örneğin gangster filmleriyle, gangsterlerin nasıl kolay para kazandıkları geniş kitlelere öğretilmeye başlanmıştır. Bu filmlerde kolay paraya ulaşabilmenin yollarını sunan her türlü zaman, mekân, nesne, karakter, eylem vb. kodlar seyirci tarafından algılanır ve bu kodlar aracilığıyla sunulan gerçeklikler kabul görebilir. Böyle bir durumda tüm bu tekrarlanan kodlar birer sinedigma olarak değerlendirilmelidir. Dönmezer'in (1994: 58) belirttiğine göre, bu filmlerdeki kolay para kazanma anlayışı, özellikle kültürel kodlarında 'kolay para' olgusu bulunan Amerika' da ‘beyaz yaka suçu'nun bir kültür hâline gelerek yoğunlaşmasında etkili olmuştur. Benzer şekilde, 'film noir (kara film)' türüne dâhil olan yapımlar, 'femme fatale' karakterlerinin giyim tarzı, tavırları, bakışları, duruşu ile toplumsal gerçekliği şekillendirmiş ve insanların giyim tarzlarını etkileyebilmiştir. Bu karakterler aynı zamanda modayı yönlendirmeyi ve araba kültürünü yaygınlaştırmayı başarmıştır (Özdemir, 2010: 28). Kültürü etkileyen şey, tüm bir kara film evreninden ziyade, kara filmlerin femme fatale karakterleridir. Dolayısıyla femme fatale, moda ve araba kültürüne etki eden bir karakter sinedigması olarak düşünülebilir. Seyirciye düşen ise sunulan bu toplumsal gerçeklikleri kabul etmek ve sinedigmalar aracılığıyla oluşturulan kültüre uyum sağlamaktan fazlası değildir. Günümüz 'gösteri toplumu' bu açıdan sinedigmalara yoğun destek sağlar.

Rancière'e (2013: 43) göre gösteri toplumunda yaşayanların durumu, Platon'un mağarasında yaşayanlarla aynıdır. Mağara duvarına yansıyanları gerçek kabul edenler, yaşamlarını değiştirmeye çalıştıkça köleliğe daha çok gömülür. Burada vurgulanan, ne gösterilenlerin altındaki gizli mesajlar ne de görüntüyle gerçek arasındaki anlaşmazlıklardır. Bunun yerine bu çalışmada savunulan düşünce, sinemasal görünümün ürettiği gerçekliğin, toplumsal hâle gelerek nasıl bir kültür oluşturabileceğidir. Bu noktada Platon'un mağara alegorisinden farklı olarak belirtilmesi gereken şey, insanların modern mağaralarında birer seyirci olarak sunulanın gerçekliğini hiç sorgulamadan yaşıyor olmasıdır. Dahası, insanlar yaşantılarıyla ilgili bazı değişikliklere gitmek istediğinde bile, sinema paradigmasını kullanan filmler, diziler, videolar ya da reklamların gerçeklikleriyle hareket etmektedir. Hareketli imgelerin gerçeklikler üzerindeki etkisi, insanları Morin'in (2005: 3) 'homo-sinematografikus' sınıflandırmasına dâhil eder; yani sinemasallaşan insana. Sinemasallaşan insan için de artık sinedigmaların sunduğu gerçekliklerden fazlasına gerek kalmayabilir.

\section{Sonuç}

Sinema, gerçeklikten aldığ öykü ve diyalog gibi biçimsel ve içeriksel değer süzgeçlerinden geçirerek yeniden üretir. Tüm bu değerler sinema paradigmasını oluşturur. Bu paradigmanın içindeki her bir değerin kendi yapısına göre sınırlı ya da sınırsız sayıda farklı varyasyonu bulunur. Örneğin diyalog için sınırsız seçenek bulunabilir; istenilen ifadeler, dil ya da cümle yapısı kullanılabilir, film için yeni bir dil bile oluşturulabilir. Buna karşın, kamera kullanımı açısından daha sınırlı bir seçme şansı bulunur. Bu seçeneklerin her biri diğerine tercih edilebilmesi ya da edilememesi açısından sinema paradigmasının ne kadar önemli bir yapı olduğunu hatırlatır.

Sinema paradigmasının içinde yer alan biçimsel ve içeriksel kodların sınırlı ve sınırsız varyasyonları, aynı zamanda gerçekliğe etkinin düzeylerini de belirler. Tam da bu noktada önemli olan, gerçeğin nasıl daha gerçekçi olduğu ya da insanlara nasıl bir gerçeklik yanılsaması yaratıldığ1 değildir. Asıl mesele, sinema paradigmasından yönetmen tarafından seçilen herhangi bir kodun, insanların gerçekliklerini nasıl etkileyebileceği ve bu durumun nasıl 
kavramsal hâle getirilebileceğidir. Bunun çözümünü sunan kavram, bu çalışmada sinedigma şeklinde yapılandırılmıştır.

Zihinsel veya toplumsal anlamda etkisi olabilen sinedigmaların sunduğu gerçekliğin kabulü, filmlerin kendi kurgu-gerçek dünyalarına inanılmasından farklıdır. Burada ortaya çıan inanç, bizzat gerçeğin zihinsel ya da toplumsal olarak yaşanabilir olduğuna duyulan inançtır. Sinedigmaların sunduğu gerçekliğe karşı inanç ortadan kalktığında, sinedigmatik yapı çöker ve sinedigma(lar) hangi gerçekliğin oluşmasına ya da değişmesine sebep olduysa, o gerçeklik üzerindeki etkisiyle birlikte varlığını da kaybeder. Dolayısıyla gerçeğin kendi gibi, bu gerçeği oluşturan sinedigmalar da kaygan bir zemine sahiptir. Eğer sinedigmalar daha geniş kitlelere yayılarak toplumsal bir gerçeklik üreticisine dönüşebilirse, kültürel yapıları etkileyecek kadar güçlenmiş olur. Bu anlamda kültürel bir oluşum gibi hareket etme fırsatına kavuşan sinedigmalar, seyir kültüründen ziyade, bir çeşit seyrin kültürünü oluşturur. $\mathrm{Bu}$ nedenle, sinedigmaların seyir kültüründen seyrin kültürüne doğru bir akışkanlık oluşturabileceği de düşünülmelidir.

Özellikle Hollywood filmleri sinema paradigmasına sayısız yenilik getirdiği gibi, tarihsel süreçte toplumların yaşadığı sosyo-ekonomik ve teknolojik değişimlere de uyum sağlamıştır. Sinema paradigmasındaki karakter, mekân, zaman, 1şık, renk, ses, diyalog gibi kodlar, alt kodlarıyla birlikte çeşitlenmiş ve genişlemiştir. Buna bağlı şekilde filmler sadece yaşanılan döneme değil, geçmiş ve geleceğe yönelik de gerçeklikler sunabilme gücüne kavuşmuştur. Özellikle geleceğe yönelik gerçeklikler, insanları henüz var olmayan bir gerçeklik ve kültür için hazırlar niteliktedir. Yarım asır önce çekilen filmlerde bile robot, cep telefonu, bilgisayar vs. teknolojileri ve bu teknolojilere bağlı olarak şekillenen toplumsal yapıları görmek bu yüzden mümkün olmuştur. Böylece Hollywood tüketimin geleceğini de garanti altına alabilmiştir. Filmlerin sunduğu gerçeklikleri bugün yaşıyor oluşumuz da aslında sinedigmaların gerçeklik üzerindeki etkisini kanıtlar niteliktedir. Günümüzde televizyon, internet, telefon, dijital platform vs. ise sinedigmaların çok daha fazla insana temas etmesine ve dolayısıyla etkisinin yayılmasina hizmet etmektedir.

Bir filmdeki sinedigmaların belirlenebilmesi için, hem literatürden hem de kişisel gözlemlerden faydalanarak öncelikle hangi gerçekliklerin filmlerle oluşturulmuş olabileceğini ortaya koymak gerekir. Nitekim bu çalışmada literatürden faydalanılmış, örnekler yardımıyla sinemanın ne tür gerçeklikler oluşturabileceği sinedigma kavramı çerçevesinde düşünülmeye çalışılmıştır. En nihayetinde sinedigmalar, insanların gerçekliklerine etki eden sinemadaki kodlar olarak düşünüldüğü için, literatür yardımıyla bu kodların neler olabileceği kadar, hangi gerçeklikler üzerinde etkisi bulunduğu da tartışılmıştır. Benzer bir yönelimle başka araştırmalar, konuyu daha derinlemesine inceleyebilir veya sadece tek bir gerçeklikten yola çıkarak filmlerin bu durum üzerindeki etkisine yoğunlaşabilir. Bu anlamda özellikle seyirci odaklı ve görüşme temeline dayalı bir araştırmayla, insanların hangi gerçeklikleri filmlerdeki hangi kod(lar)dan elde ettiğine yönelik ayrıntılı bilgilere ulaşılabilir. "Seyircinin gerçeklik algısında filmlerin rolü nedir? Seyirci aslında olmayan veya farklı sunulan bir gerçekliğe inanmakta mıdır? Bu gerçekliğe inanmasını sağlayan filmdeki karakter, kamera, kurgu vs. kodlarından ya da bunların altkodlarından hangisidir/hangileridir?" gibi temel sorularla sinedigmaların neler olduğu ve insanlar üzerindeki etkisine yönelik araştırmalar gerçekleştirilebilir. Örneğin "psikiyatriste gidildiğinde divana uzanma" gibi bir olgunun insanlar için ne kadar gerçek olduğuna ve bu tür bir gerçeklikte filmlerin rolü olup olmadığına yönelik bir araştırma, filmlerdeki divana uzanma kodunun zihinsel veya toplumsal gerçeklik üretebilen bir sinedigma olup olmadığı üzerine anlama ulaşılmasını sağlayabilir. Bu açıdan, sinedigmalara yönelik araştırmalarda sabit parametrelerden yola çıkmak değil, hangi kodların gerçekliğe etki edebileceğini düşünmek ve bu kodların aynı zamanda bir sinedigma olup olmadığını da sorgulamak gerekir. Zira aynı filmdeki farklı kodlar, farklı seyircilerin gerçekliğine etki edebilir. Dolayısıyla bir seyirci için sinedigma olarak adlandırılacak bir kod, diğeri için geçerli 
olmayabilir ve bu durum parametrelerin sabitlenemeyeceğini göstermektedir. Eğer sunulan gerçekliğe karşı ortak bir inanç oluşmuşsa, bunu sağlayan sinedigmalar, seyrin kültürünü etkilemiştir.

\section{Kaynakça}

Abisel, N. (1995). Popüler Sinema ve Türler. İstanbul: Alan.

Adanir, O. (2012). İlkel Toplumdan Melodramlar Evrenine. İstanbul: Hayalperest.

Adorno, W. T. (2007). Kültür Endüstrisi. İstanbul: İletişim.

Baker, U. (2012). Beyin Ekran. (E. Berensel, Der.). İstanbul: Birikim.

Balàzs, B. (1970). Theory of The Film. (E. Bone, Trans.). London: Dennis Dobson.

Baudrillard, J. (2005). Şeytana Satılan Ruh ya da Kötülüğün Egemenliği. (Çev. O. Adanır). Ankara: Doğu Batı.

Baudrillard, J. (2006). Kusursuz Cinayet. (N. Sevil, Çev.). İstanbul: Ayrıntı.

Baudrillard, J. (2010). Sanat Komplosu: Yeni Sanat Düzeni ve Çă̆daş Estetik 1. (E. Gen ve I. Ergüden, Çev.). İstanbul: İletişim.

Baudrillard, J. (2011). Simülakrlar ve Simülasyon. (O. Adanır, Çev.). Ankara: Doğu Batı.

Benjamin, W. (2002). Pasajlar. (A. Cemal, Çev.). İstanbul: Yapı Kredi.

Berger, J. (2012). Görme Biçimleri. (Y. Salman, Çev.). İstanbul: Metis.

Bernard, W. (2006). Hakikat ve Hakikatlilik (E. Demirel, Çev.). İstanbul: Ayrıntı.

Bordwell, D. \& Thompson, K. (2002). Film History: An Introduction. New York: McGrawHill (e-book).

Bourdieu, P. (1990). In Other Words: Essays Towards a Reflexive Sociology. California: Stanford University.

Burnett, R. (2012). İmgeler Nasıl Düşünür? (G. Pusar, Çev.). İstanbul: Metis.

Cavell, S. (1979). The World Viewed: Reflections on The Ontology of Film. Cambridge: Harward University.

Cevizci, A. (1999). Felsefe Sözlüğüu. İstanbul: Paradigma.

Cündioğlu, D. (2012). Sinema ve Felsefe. İstanbul: Kap1.

Deleuze, G. (1997). Cinema 2: The Time-Image. (H. Tomlinson \& R. Galeta, Trans.). Minneapolis: University of Minnesota (e-book).

Diken, B. ve Laustsen, B. C. (2011). Filmlerle Sosyoloji. (S. Ertekin, Çev.). İstanbul: Metis.

Doctorow, E. L. (2000). City of God. New York: Random House. 
Faure, E. (2006). Elie Faure: Sinema Sanatı. (M. Gönen, Der.). İstanbul: Es.

Fanon, F. (2007). Yeryüzünün Lanetlilieri. (Ş. Süer, Çev.). İstanbul: Versus.

Foucault, M. (2013). Bu Bir Pipo Değildir. (S. Hilav, Çev.). İstanbul: Yap1 Kredi.

Frampton, D. (2013). Filmozofi (C. Soydemir, Çev.). İstanbul: Metis.

Gabbard, O. G. ve Gabbard, K. (2009). Psikiyatri ve Sinema. (Y. Eradam ve H. Satılmışoğlu, Çev.). İstanbul: Okuyan Us.

Gültekin, G. (2018). Popüler Sinemada Sanal Özgürlük Sunumu: Pi'nin Yaşamı Örneği. Abant Kültürel Araştırmalar Dergisi, 3(5), 1-19.

Kakınç, D. T. (1993). 100 Filmde Başlangıçtan Günümüze Gangster Filmleri. Ankara: Bilgi.

Kawana, S. (2008). Murder Most Modern: Detective Fiction and Japanese Culture. Minnesota: University of Minnesota.

Kellner, D. (2013). Sinema Savaşlar: Bush-Cheney Döneminde Hollywood Sineması ve Siyaset. (G. Koca, Çev.). İstanbul: Metis.

Kırel, S. (2012). Kültürel Çalışmalar ve Sinema. İstanbul: Kırmızı Kedi.

Laing, D. R. (2012). Bölünmüş Benlik. (E. Akça, Çev.). İstanbul: Pinhan.

Maccannel, F. J. (2014). İki Korku Arasında. (T. McGowan ve S. Kunkle, Der.). Lacan ve Çă̆daş Sinema. (Y. Ertuğrul ve C. Turan, Çev.). İstanbul: Say.

Marin, L. (2013). Imgenin İktidarları. (M. Cedden, Çev.). Ankara: Dost.

McGowan, T. (2014). Fantezilerimizle Mücadele Etme: Karanlık Şehir ve Psikanalizin Politikası. (T. McGowan ve S. Kunkle, Der.). Lacan ve Çă̆daş Sinema. (Y. Ertuğrul ve C. Turan, Çev.). İstanbul: Say.

Metz, C. (2012). Sinemada Anlam Üstüne Denemeler 1. (O. Adanır, Çev.). İstanbul: Hayalperest.

Mitry, J. (1989). Sinema Estetiği ve Psikolojisi. (O. Adanır, Çev.). İzmir: Dokuz Eylül Üniversitesi Güzel Sanatlar Fakültesi.

Monaco, J. (2010). Bir Film Nasıl Okunur? (E. Yılmaz, Çev.). İstanbul: Oğlak.

Morin, E. (2005). The Cinema or The Imaginary Man. Minneapolis: University of Minnesota.

Özdemir, T. S. (2010). Yeni Kara Filmler. Ankara: Nirengi.

Pamuk, O. (2011). Kara Kitap. İstanbul: İletişim.

Pezzella, M. (2006). Sinemada Estetik. (F. Demir, Çev.). Ankara: Dost.

Platon (2011). Devlet. (S. Eyüboğlu ve M. A. Cimcoz, Çev.). İstanbul: Türkiye İş Bankası. 
Rancière, J. (2013). Özgürleşen Seyirci. (E. B. Şaman, Çev.). İstanbul: Metis.

Ryan, M. ve Kelner, D. (2010). Politik Kamera. (E. Özsayar, Çev.). İstanbul: Ayrıntı.

Şentürk, R. (2011). Postmodern Kaos ve Sinema. İstanbul: Avrupa Yakası.

Wayne, M. (2009). Politik Film. (E. Yılmaz, Çev.). İstanbul: Yordam.

Wood, J. (2010). Kurmaca Nasıl İşler? (E. Bodur, Çev.). İstanbul: Ayrıntı.

Yücel, H. (2013). İmgeden Yoruma. İstanbul: Ayrıntı.

Zizek, S. (2011). İdeolojinin Yüce Nesnesi. (T. Birkan, Çev.). İstanbul: Metis. 